\title{
Humoral and cellular responses to a non-adjuvanted monovalent H1N1 pandemic influenza vaccine in hospital employees
}

Ma Teresa Herrera', Yolanda Gonzalez , Esmeralda Juárez , Fernando Hernández-Sánchez , Claudia Carranza ${ }^{1}$ Carmen Sarabia', Silvia Guzman-Beltran¹, Ma Eugenia Manjarrez², Marcela Muñoz-Torrico', Lourdes Garcia-Garcia³, Eduardo Sada ${ }^{1}$ and Martha Torres ${ }^{1 *}$

\begin{abstract}
Background: The efficacy of the H1N1 influenza vaccine relies on the induction of both humoral and cellular responses. This study evaluated the humoral and cellular responses to a monovalent non-adjuvanted pandemic influenza A/H1N1 vaccine in occupationally exposed subjects who were previously vaccinated with a seasonal vaccine.

Methods: Sixty healthy workers from a respiratory disease hospital were recruited. Sera and peripheral blood mononuclear cells (PBMCs) were obtained prior to and 1 month after vaccination with a non-adjuvanted monovalent 2009 H1N1 vaccine (Influenza A (H1N1) 2009 Monovalent Vaccine Panenza, Sanofi Pasteur). Antibody titers against the pandemic $\mathrm{A} / \mathrm{H} 1 \mathrm{~N} 1$ influenza virus were measured via hemagglutination inhibition $(\mathrm{HI})$ and microneutralization assays. Antibodies against the seasonal HA1 were assessed by ELISA. The frequency of IFN- - -producing cells as well as CD4 ${ }^{+}$and $\mathrm{CD}^{+} \mathrm{T}$ cell proliferation specific to the pandemic virus A/H1N peptides, seasonal $\mathrm{H} 1 \mathrm{~N} 1$ peptides and seasonal H3N2 peptides were assessed using ELISPOT and flow cytometry.

Results: At baseline, $6.7 \%$ of the subjects had seroprotective antibody titers. The seroconversion rate was $48.3 \%$, and the seroprotection rate was $66.7 \%$. The geometric mean titers (GMTs) were significantly increased (from 6.8 to $64.9, \mathrm{p}<0.05)$. Forty-nine percent of the subjects had basal levels of specific IFN- - -producing $T$ cells to the pandemic $\mathrm{A} / \mathrm{H} 1 \mathrm{~N} 1$ peptides that were unchanged post-vaccination. $\mathrm{CD}^{+} \mathrm{T}$ cell proliferation in response to specific pandemic $\mathrm{A} / \mathrm{H} 1 \mathrm{~N} 1$ virus peptides was also unchanged; in contrast, the antigen-specific proliferation of $\mathrm{CD}^{+} \mathrm{T}$ cells significantly increased post-vaccination.
\end{abstract}

Conclusion: Our results indicate that a cellular immune response that is cross-reactive to pandemic influenza antigens may be present in populations exposed to the circulating seasonal influenza virus prior to pandemic or seasonal vaccination. Additionally, we found that the pandemic vaccine induced a significant increase in $C D 8^{+} \mathrm{T}$ cell proliferation.

Keywords: Pandemic influenza, H1N1, Vaccine, Cellular response, Proliferation, Humoral response

\section{Background}

In the spring of 2009, the most recent pandemic of the A/H1N1 influenza virus originated in Mexico, eventually becoming a major worldwide public health threat [1]. With the goal of protecting high-risk populations, different vaccine formulations were produced that yielded high

\footnotetext{
* Correspondence: marthatorres98@yahoo.com

'Department of Microbiology, Instituto Nacional de Enfermedades Respiratorias Ismael Cosío Villegas, Tlalpan 4502, Tlalpan, Mexico City 14080, Mexico

Full list of author information is available at the end of the article
}

seroprotection and seroconversion rates in healthy subjects; high antibody titers were observed beginning on day 10 after vaccination and were sustained up to day 45 [2-4]. Mexican health authorities began by administering the vaccine to high-risk groups including hospital employees who had previously received the seasonal influenza vaccine. The employees of the National Institute of Respiratory Diseases in Mexico City were vaccinated with the non-adjuvanted monovalent pandemic influenza A/H1N1 vaccine manufactured by Sanofi Pasteur, a vaccine that was based on the virus strain recommended by

\section{Ciomed Central}

(c) 2013 Herrera et al.; licensee BioMed Central Ltd. This is an open access article distributed under the terms of the Creative Commons Attribution License (http://creativecommons.org/licenses/by/2.0), which permits unrestricted use, distribution, and reproduction in any medium, provided the original work is properly cited. 
the World Health Organization for the development of the influenza A (H1N1) vaccine [5]. The antibody response to the Sanofi Pasteur vaccine has been reported to range from good to moderate in different high-risk populations [6-9]. Nevertheless, our knowledge regarding the induction of cellular responses to this vaccine remains limited.

In addition to a humoral response, this vaccine is expected to promote the development of cell-mediated immune responses [10]. Cellular immune responses, mediated by $\mathrm{CD}^{+}$and $\mathrm{CD} 8^{+} \mathrm{T}$ cells, contribute to essential surveillance against the influenza virus via cytokine modulation and the cross-reactivity that exists among virusspecific cytotoxic T cells [11]. Moreover, the use of the IFN- $\gamma$ ELISPOT assay has successfully demonstrated the existence of circulating memory $\mathrm{CD}_{4}^{+}$and $\mathrm{CD} 8^{+}$ $\mathrm{T}$ cells that are cross-reactive with the pandemic virus in healthy donors irrespective of any prior seasonal vaccination or exposure to this novel virus [11-14].

The present study was initiated after the first pandemic wave in Mexico occurred and was conducted as a longitudinal study in employees of the National Institute of Respiratory Diseases in Mexico City. This study was conducted to evaluate the immunogenicity of a singledose administration of a monovalent non-adjuvanted pandemic influenza $\mathrm{A} / \mathrm{H} 1 \mathrm{~N} 1$ vaccine in individuals who had previously received the trivalent 2008 or 2009 seasonal influenza vaccine. We evaluated the level of protection of the pandemic $\mathrm{A} / \mathrm{H} 1 \mathrm{~N} 1$ vaccine according to specific antibody titers as well as human influenza-specific $\mathrm{T}$ cell responses.

\section{Methods}

\section{Study group}

We recruited 60 healthy subjects at random who intended to receive the pandemic influenza vaccine through a public institutional vaccine program for employees of the National Institute of Respiratory Diseases in Mexico City; of these subjects, 45 (75\%) had received the 2009 seasonal vaccine (Fluzone 2009-2010 trivalent A/Brisbane/59/2007 (H1N1)-like, A Brisbane/10/2007 (H3N2)-like and B/Brisbane/60/2008-like strains) in October 2009, and 5 subjects $(8.3 \%)$ had received the 2008 trivalent seasonal vaccine (Fluzone 2008-2009 A/Solomon Islands/3/2006 (H1N1), A Wisconsin /67/2005 (H3N2) B Malaysia/2506/ 2004). The authors did not vaccinate the cohort, and this was not a trial study. The subjects were recruited from December 2009 to January 2010. All volunteers received a single dose of the non-adjuvanted monovalent 2009 H1N1 vaccine (Influenza A (H1N1) 2009 Monovalent Vaccine Panenza, Sanofi Pasteur). The volunteers consented to undergo venipuncture prior to and $1 \mathrm{month}$ after pandemic influenza $\mathrm{A} / \mathrm{H} 1 \mathrm{~N} 1$ vaccination. We obtained paired samples for the isolation of serum and peripheral blood mononuclear cells (PBMCs). All participants signed an informed consent form, and the local Institutional Review Boards approved this protocol.

\section{Peptides}

We used custom-designed peptides that were synthesized by Enzo Life Sciences (Ann Arbor, MI, U.S.A.) and designed on the basis of their conservation level for viral strain discrimination. The regions of the hemagglutinin (HA) sequences of the 2009 pandemic H1N1 and seasonal $\mathrm{H} 1 \mathrm{~N} 1$ and $\mathrm{H} 3 \mathrm{~N} 2$ viruses that were unique to these viruses were selected and analyzed. All HA sequences from the National Center for Biotechnology Information (NCBI) Influenza Virus Sequence Database available in 2009 were downloaded and aligned using the ClustalW (FASTA) tool, which is free and available on the NCBI website [15]. Protein consensus sequences were generated and independently analyzed for each virus subtype; the scores for conservation or synonymous substitutions were identified for each position. The selected sequences contained putative MHC class I and class II epitopes with low and high affinity for HLA alleles that are frequently found in the Mexican population [16]. These sequences were validated with the SYFPEITHI epitope prediction tool and the ProPred MHC class II binding prediction server [17] (see Additional file 1: Table S1).

Lyophilized peptides were dissolved in RPMI 1640 medium (Lonza, Walkersville, MD) containing 20\% dimethyl sulfoxide (DMSO, Sigma-Aldrich, St Louis, MO), frozen at $-70^{\circ} \mathrm{C}$ and diluted at a ratio of 1:1,000 with RPMI 1640 medium containing $2 \mathrm{mM}$ L-glutamine (Sigma-Aldrich) and $50 \mu \mathrm{g} / \mathrm{ml}$ gentamicin sulfate (Lonza), herein termed "supplemented medium".

\section{Sera and cells}

After blood samples were collected from the volunteers, serum was obtained via centrifugation and stored at $-70^{\circ} \mathrm{C}$ until use. PBMCs were isolated from heparinized blood diluted at a 1:2 ratio with supplemented medium and separated via centrifugation using a lymphocyte separation solution (Lonza). The PBMCs were washed, counted and cryopreserved in fetal bovine serum (FBS, Hyclone, Logan, UT) containing $10 \%$ DMSO at $-70^{\circ} \mathrm{C}$ until use. For the cellular response analysis, cryopreserved PBMCs were thawed and re-suspended in supplemented medium (viability $\geq 90 \%$ ).

\section{Antibody detection}

Antibodies specific to the influenza pandemic virus were identified using hemagglutination inhibition and microneutralization assays. Briefly, serial 2-fold dilutions of the previously inactivated serum were assayed for their ability to inhibit the agglutination of chicken red blood cells in the presence of the A/H1N1/California/07/2009 
influenza virus. Serum dilutions (starting at 1:5) were tested in duplicate, and titers are expressed as the reciprocal of the highest dilution that produced complete hemagglutination or $50 \%$ neutralization, respectively [18]. The antibody response was assessed using the criteria of the European Agency for the Evaluation of Medicinal Products (EMA) for 18- to 60-year-old subjects and was based on the geometric mean titers (GMTs), seroprotection rate (percentage of subjects with $\mathrm{HI}$ antibody titers $\geq 1: 40$ ) and seroconversion rate (percentages of subjects with either pre-vaccination $\mathrm{HI}$ antibody titers $\leq 1: 10$ and post-vaccination titers $\geq 1: 40$ or pre-vaccination $\mathrm{HI}$ antibody titers $\geq 10$ and at least a 4-fold increase in postvaccination $\mathrm{HI}$ antibody titers). In accordance with the EMA, these criteria include a seroprotection rate $\geq 70 \%$, a seroconversion rate $\geq 40 \%$ and a GMT fold increase of 2.5; these 3 parameters must be fulfilled for acceptable pandemic influenza vaccines [19]. We also determined the levels of anti-H1 hemagglutinin (HA1) IgG antibodies in the serum using a commercial ELISA kit (Cusabio, Biotech Co., Newark, DE) according to the manufacturer's instructions. The results are expressed as the OD at $450 \mathrm{~nm}$. A sample was considered seropositive when its OD was $\geq 0.4$.

\section{Human IFN- $\gamma$ ELISPOT assay}

The frequency of antigen-specific IFN- $\boldsymbol{\gamma}$-producing $\mathrm{T}$ cells upon stimulation with HA peptides was assessed using ELISPOT, as previously described [20,21]. In brief, multiscreen 96-well filter plates (Millipore Corporation, Billerica, MA) were incubated overnight at $4^{\circ} \mathrm{C}$ with anti-human IFN- $\gamma$ antibody (Endogen, Woburn, MA). The plates were blocked with $1 \%$ bovine serum albumin (BSA, Calbiochem, La Jolla, CA), and $2.5 \times 10^{5} \mathrm{PBMCs} /$ well were seeded and incubated for $48 \mathrm{~h}$ with individual peptides $(10 \mu \mathrm{g} / \mathrm{ml})$, a mix of peptides $(2 \mu \mathrm{g} / \mathrm{ml}$ each) or the recombinant HA A/H1N1/California/06/2009 (Immune Tech., Foster City, CA). Phytohemagglutinin (10 $\mu \mathrm{g} / \mathrm{ml})$ (PHA, Sigma-Aldrich) was included as the positive control, and the medium alone culture served as the negative control (background). The cells were removed, and biotinylated-anti-human IFN- $\gamma$ antibody (Endogen) was added and allowed to incubate for 2 h. Peroxidase-streptavidin (Dako, Glostrup, Denmark) was added, and the spots were visualized after the addition of 1\% 3-amino-9-ethylcarbazole (AEC, Pierce, Rockford, IL). Spot-forming cells (SFCs) were counted using an ImmunoSpot reader (Cellular Technology Ltd, Cleveland, $\mathrm{OH}$ ). The frequency of IFN- $\gamma$-producing cells was calculated by averaging the number of spots in duplicate wells after background subtraction. The results are expressed as SFCs $/ 10^{6}$ PBMCs. Subjects whose IFN- $\gamma$ response exceeded the background response by at least 6 spots were considered specific responders.

\section{T cell proliferation assay}

To evaluate the proliferative response after pandemic $\mathrm{A} / \mathrm{H} 1 \mathrm{~N} 1$ vaccination, we examined the percentage of proliferating peripheral $\mathrm{CD}^{+}$and $\mathrm{CD}^{+} \mathrm{T}$ cells following stimulation with $\mathrm{H} 1 \mathrm{~N} 1$ peptides. This analysis utilized the carboxyfluorescein diacetate succinimidyl ester (CFSE) dilution model, in which the CFSE signal is divided between daughter cells and shows peaks with diminishing fluorescence at an approximate ratio of 0.5 per cell division. We analyzed each round of cell division of $\mathrm{CD}^{+}$ and $\mathrm{CD}^{+} \mathrm{T}$ cells in response to the $\mathrm{H} 1 \mathrm{~N} 1$ peptides. Briefly, the PBMCs were labeled with CFSE (Sigma-Aldrich), placed in a $\mathrm{PBS} / 2 \% \mathrm{BSA}$ solution for $15 \mathrm{~min}$ at $37^{\circ} \mathrm{C}$ and washed twice with PBS. The cells were then seeded in ultralow attachment 24-well plates (Costar-Corning Incorporated, Corning, NY) at $1 \times 10^{6} \mathrm{PBMCs} /$ well and stimulated with $10 \mu \mathrm{g} / \mathrm{ml}$ of the individual influenza peptides. PHA $(10 \mu \mathrm{g} / \mathrm{ml})$ was included as a positive control, and medium alone served as the negative control. The plates were incubated at $37^{\circ} \mathrm{C}$ with $5 \% \mathrm{CO}_{2}$ for 7 days. The cells were subsequently stained with monoclonal anti-human antibodies including CD3-PE-Texas Red (Invitrogen Gibco, Grand Island, NY), CD8-PE-Cy7 and CD4-APC-Cy7 (BioLegend, San Diego, CA). Then, $1 \times 10^{4}$ events were recorded for each condition using a FACSCanto II flow cytometer (Becton Dickinson), and the data were analyzed with the FlowJo proliferation platform (FlowJo 9.4.10, Tree Star, Inc., Ashland, OR). The peptide-specific proliferation of $\mathrm{CD}^{+} / \mathrm{CD}^{+} / \mathrm{CFSE}^{+}$ or $\mathrm{CD}^{+} / \mathrm{CD}^{+} / \mathrm{CFSE}^{+}$cells was calculated by subtracting the number of proliferating cells in the negative control. Individuals with a positive proliferative response were defined as subjects with $\geq 2 \%$ proliferating cells (based on the summed responses to peptides 1 and 2 and the total proliferation).

\section{Statistical methods}

Differences in antibody production and IFN- $\gamma$ responses elicited by the specific peptides and the proliferation of $\mathrm{CD}^{+}$and $\mathrm{CD} 4^{+} \mathrm{T}$ cells pre- and post-vaccination were analyzed using the Wilcoxon signed rank test. Differences in proliferation between the influenza serotypes were analyzed using the Kruskal-Wallis test, followed by Dunn's multiple comparison test. Associations of age, gender and area of work at the hospital with pre- and post-vaccination antibody titers were assessed using the chi-square test. We used the Spearman rank correlation test to assess whether age, gender or work activity at the hospital was associated with neutralizing antibody titers or $\mathrm{T}$ cell responses. To our knowledge there are no published data describing the mean difference in $\mathrm{CD}^{+} \mathrm{T}$ cells between pre- and post-H1N1 pandemic influenza vaccination. We therefore estimated our sample size based on an analysis of the first 10 pairs of subjects among whom we observed that the 
difference in response was not normally distributed (median 3.8, IQR (1.44-7.09). We calculated the sample size needed for a two-sample t-test (alpha $=0.05$ and beta $=0.8$ ) using a mean of 3.8 and standard deviation of 4, arriving at 33 pairs, and then adjusted the sample size based on the asymptotic relative efficiency of the Mann-Whitney $U$ relative to the $\mathrm{t}$-test (worst case scenario, dividing 33 by 0.864), arriving at 38 pairs [22].

The statistical analyses were performed using SPSS 15.0 for Windows (SPSS, Chicago, IL) and Prism 5.0 (GraphPad, La Jolla, CA). Two-tailed p-values $<0.05$ were considered statistically significant.

\section{Results and discussion}

\section{Description of the cohort}

Sixty subjects were enrolled in the present study; all of the subjects were employees of the National Institute of Respiratory Diseases in Mexico City, which is a reference center for pandemic influenza patients. All subjects were actively working during the pandemic wave of the influenza A/H1N1 virus (2009), which originated in Mexico. Forty-five (75\%) of the subjects were previously vaccinated with the trivalent influenza seasonal vaccine in October 2009 , and $5(8.3 \%)$ of the subjects were vaccinated with the 2008 trivalent influenza seasonal vaccine before October 2009. The occupations of the participants included research, clinical practice and administrative functions. None of the subjects had been diagnosed as having influenza prior to or after $\mathrm{A} / \mathrm{H} 1 \mathrm{~N} 1$ vaccination. Table 1 summarizes the characteristics of the study group. The variables of age, gender, prior seasonal vaccination status and area of work were not associated or correlated with the humoral or cellular responses described below.

\section{Antibody responses to the pandemic $A / H 1 N 1$ vaccine}

The immunogenicity of the vaccine against influenza $\mathrm{A} / \mathrm{H} 1 \mathrm{~N} 1$ was assessed according to the antibody titer after vaccination. Here, we determined the serum levels of antibodies against the pandemic virus using a hemagglutination inhibition assay, which is a standard assay used in the process of licensing influenza vaccines. Prior to 2009

Table 1 Demographics of the study group

\begin{tabular}{lc}
\hline $\mathrm{N}$ & Value \\
\hline Female & 60 \\
Male & $58 \%$ \\
Age & $42 \%$ \\
Immunization with 2008-2009 seasonal vaccine & $37.1 \pm 8.8$ \\
Immunization with 2009-2010 seasonal vaccine & $8.3 \%$ \\
No prior seasonal vaccination & $75.0 \%$ \\
Work-related direct contact with patients & $16.7 \%$ \\
\hline
\end{tabular}

$\mathrm{A} / \mathrm{H} 1 \mathrm{~N} 1$ virus vaccination, the baseline seroprotective rate of the subjects was $6.7 \%$, and the GMT was 6.8 (Figure 1a and Table 2). The proportion of subjects with titers $\geq 1: 40$ in the hemagglutination inhibition assay at baseline was lower than expected for such an exposed population considering the previous vaccination with the 2008 and 2009 seasonal influenza vaccines in $83 \%$ of the subjects; these titers were also lower than those previously reported for health care workers [6]. Antibodies are expected to be present in healthy subjects prior to vaccination with the pandemic $\mathrm{A} / \mathrm{H} 1 \mathrm{~N} 1$ vaccine $[23,24]$ and are likely elicited by natural exposure to cross-reactive influenza strains [25].

After vaccination, the seroconversion (48.3\%) and seroprotection (66.7\%) rates increased, as did the antibody GMTs $(p<0.0001)$. Although pandemic influenza vaccination induced a humoral response with a high fold increase in the GMT (Table 2), our study most likely lacked sufficient power to detect the seroprotection rate required for vaccination success according to the international criteria [19].

Furthermore, we performed a virus microneutralization assay and observed a significant increase in the virus neutralizing antibody titers after vaccination $(\mathrm{p} \leq 0.0001$, Figure $1 \mathrm{~b}$ ). Although there are no standardized criteria to apply for this method, our results showed that pandemic influenza vaccination induced a limited humoral response in this study group.

It has been reported that recent seasonal vaccination can decrease antibody responses to the pandemic $\mathrm{A} / \mathrm{H} 1 \mathrm{~N} 1$ vaccine $[6,26,27]$, but the mechanism of such a phenomenon has not been explored. We investigated whether the pre-existence of anti-HA1 antibodies played a role in the decrease of the pandemic $\mathrm{A} / \mathrm{H} 1 \mathrm{~N} 1$ vaccine antibody responses in a subgroup of our study cohort that included subjects who were seronegative for the specific pandemic antibodies and were vaccinated with the seasonal 2009 vaccine. We divided this group into individuals who presented anti-HA1 antibodies prior to pandemic A/H1N1 vaccination and individuals who did not. Our results showed that after pandemic $\mathrm{A} / \mathrm{H} 1 \mathrm{~N} 1$ vaccination, the subjects without anti-HA1 antibodies prior to vaccination $(n=9)$ showed higher hemagglutination inhibition antibody titers compared with subjects with anti-HA1 antibodies prior to vaccination $(\mathrm{n}=13)$ (GMT 108.9 vs. GMT 37.75, respectively, $\mathrm{p}=0.14$ ). However, this difference was not statistically significant. Thus, we cannot conclude that pre-existing antibodies to the seasonal vaccine played a role in the induction of antibodies against the pandemic $\mathrm{A} / \mathrm{H} 1 \mathrm{~N} 1$ vaccine (Figure $1 \mathrm{c}$ ).

\section{T cell responses to pandemic influenza peptides IFN- $\boldsymbol{\gamma}$ production}

To evaluate vaccine-induced $T$ cell reactivity, we assessed IFN- $\gamma$ production using PBMCs stimulated in vitro with 

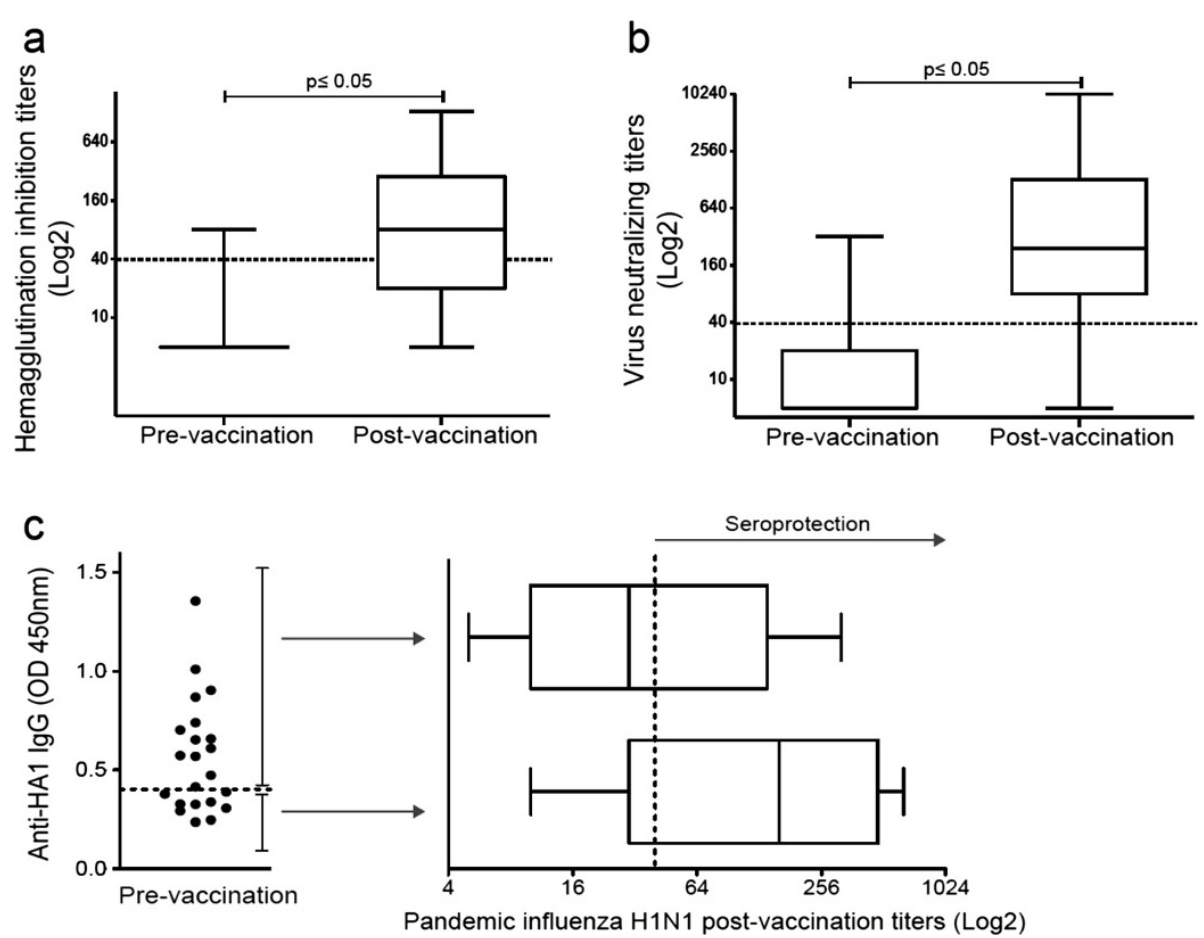

Figure 1 Increased humoral responses after pandemic influenza A/H1N1 vaccination. Specific antibodies against the pandemic influenza virus $\mathrm{A} / \mathrm{H} 1 \mathrm{~N} 1$ were measured via (a) hemagglutination inhibition and (b) microneutralization. The box plots show quartiles and medians. The dotted lines indicate a cut-off value of 1:40, with $p \leq 0.05$ (pre-vaccination vs. post-vaccination), as determined using the Wilcoxon singed rank test $(n=60)$. (c) The presence of lgG antibodies against hemagglutinin A/H1N1 (HA1) was assessed in sera obtained prior to H1N1 vaccination using ELISA, with the dotted line indicating the cut-off value $(n=22)$. The antibody titers against the pandemic influenza virus A/H1N1 were assessed post-vaccination in sera from individuals with $(n=13)$ or without $(n=9)$ anti-HA1 antibodies prior to vaccination using the hemagglutination inhibition assay. The depicted box plots show the quartiles and medians. The dotted line indicates the protective cut-off value.

specific peptides from pandemic $\mathrm{A} / \mathrm{H} 1 \mathrm{~N} 1$ and the seasonal virus using ELISPOT. The baseline frequency of the IFN- $\gamma$-producing cells was moderate and comparable to that reported by others $[28,29]$. Prior to vaccination, a specific response to viral serotype peptides was observed in a number of subjects and ranged from $22 \%$ for the seasonal $\mathrm{H} 3 \mathrm{~N} 2$ peptide to $49 \%$ for the pandemic A/H1N1 peptide 1 (Figure 2). Unexpectedly, after vaccination, IFN- $\gamma$ production did not increase in response to the specific pandemic A/H1N1 peptides or to peptides from the seasonal strains.
There is controversy in the published data regarding the specifics of IFN- $\gamma$ production. For example, it has been reported that only $\mathrm{CD} 4^{+}$and not $\mathrm{CD} 8^{+} \mathrm{T}$ cells produce IFN- $\gamma$ in response to specific peptides after vaccination and that this cellular response is low but steady [30]. In contrast, another study reported that subjects without confirmed exposure to the pandemic $\mathrm{A} / \mathrm{H} 1 \mathrm{~N} 1$ virus could generate higher numbers of IFN- $\gamma$ spots from both $\mathrm{CD} 4^{+}$ and $\mathrm{CD}^{+} \mathrm{T}$ cells to either pandemic A/H1N1 infection with the whole vaccine virus or toward a peptide pool $[31,32]$. In any case, no correlation was observed regarding

Table 2 Humoral response after pandemic H1N1 vaccination

\begin{tabular}{|c|c|c|c|c|}
\hline & \multicolumn{2}{|c|}{ Hemagglutination inhibition } & \multicolumn{2}{|c|}{ Microneutralization assays } \\
\hline & Pre-vaccination & Post-vaccination & Pre-vaccination & Post-vaccination \\
\hline $\mathrm{N}$ & 60 & 60 & 60 & 60 \\
\hline Seroprotection rate $\%^{\mathrm{a}}$ & 6.7 & $66.7^{d}$ & NA & NA \\
\hline Seroconversion rate $\%^{\mathrm{b}}$ & NA & 48.3 & NA & NA \\
\hline$G M T^{c}$ & 6.8 & $64.9^{\mathrm{d}}$ & 10.7 & $288.4^{d}$ \\
\hline GMT Fold-change & NA & 9.5 & NA & 26.9 \\
\hline
\end{tabular}

${ }^{a}$ Seroprotection rate $=$ percentage of subjects with hemagglutinin inhibition titers $\geq 1: 40$.

${ }^{\mathrm{b}}$ Seroconversion rate $=$ percentage of subjects with pre-vaccination hemagglutinin inhibition titers $\leq 1: 10$ and post-vaccination titers $\geq 1: 40$.

${ }^{\mathrm{C}} \mathrm{GMT}=$ geometric mean titer.

${ }^{d} p \leq 0.05$ vs pre-vaccination. 

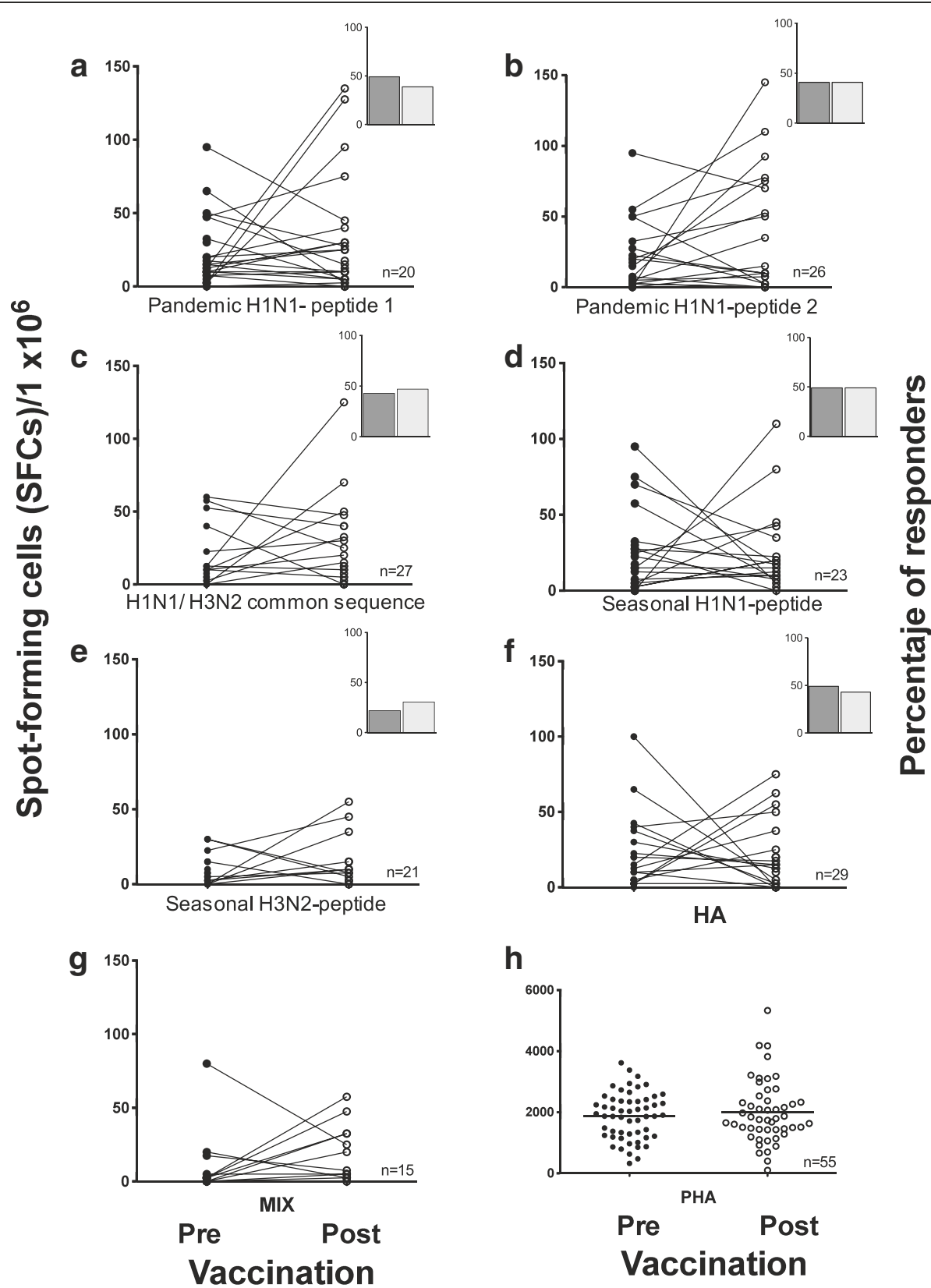

h

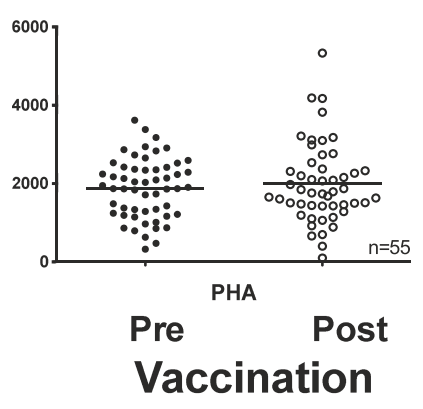

Figure 2 Frequency of IFNY-producing cells in response to pandemic influenza peptides. Pre- and post-vaccination PBMCs were stimulated with $10 \mu \mathrm{g} / \mathrm{ml}$ of pandemic H1N1 peptides 1 and 2, a common H1N1/H3N2 sequence, the seasonal H1N1 and H3N2 peptides (a-e), the whole HA protein (f), a mixture of all the peptides $(\mathbf{g})$ or PHA $(\mathbf{h})$ for $48 \mathrm{~h}$. Cells producing IFN- $\gamma$ were enumerated using an ex-vivo ELISPOT assay. The results are expressed as the number of SFCs per $10^{6}$ PBMCs. Insets depict the percentage of subjects with a positive IFN- $\boldsymbol{\gamma}$ response pre- (dark) and post-(light) vaccination.

antibody production in these studies; we also failed to detect such a correlation in our study. In light of these findings, our observation of the absence of a post-vaccination response was unexpected and may be due to the selectivity of the immune response of antigen-specific cells that can produce cell mediators, such as cytotoxic effectors, in addition to IFN- $\gamma[11]$.

\section{$C D 4^{+}$and $C D 8^{+} T$ cell proliferative responses}

Prior to H1N1 vaccination, we observed proliferative responses in peripheral $\mathrm{CD}_{4}^{+}$and $\mathrm{CD} 8^{+} \mathrm{T}$ cells to pandemic A/H1N1 peptides 1 and 2 . Following A/H1N1 vaccination, the proportion of proliferative $\mathrm{CD}^{+} \mathrm{T}$ cells significantly increased ( $\mathrm{p}<0.05)$; however, the proliferation of $\mathrm{CD} 4^{+} \mathrm{T}$ cells did not significantly increase $(\mathrm{p}=0.149)$ (Figure 3 ). 


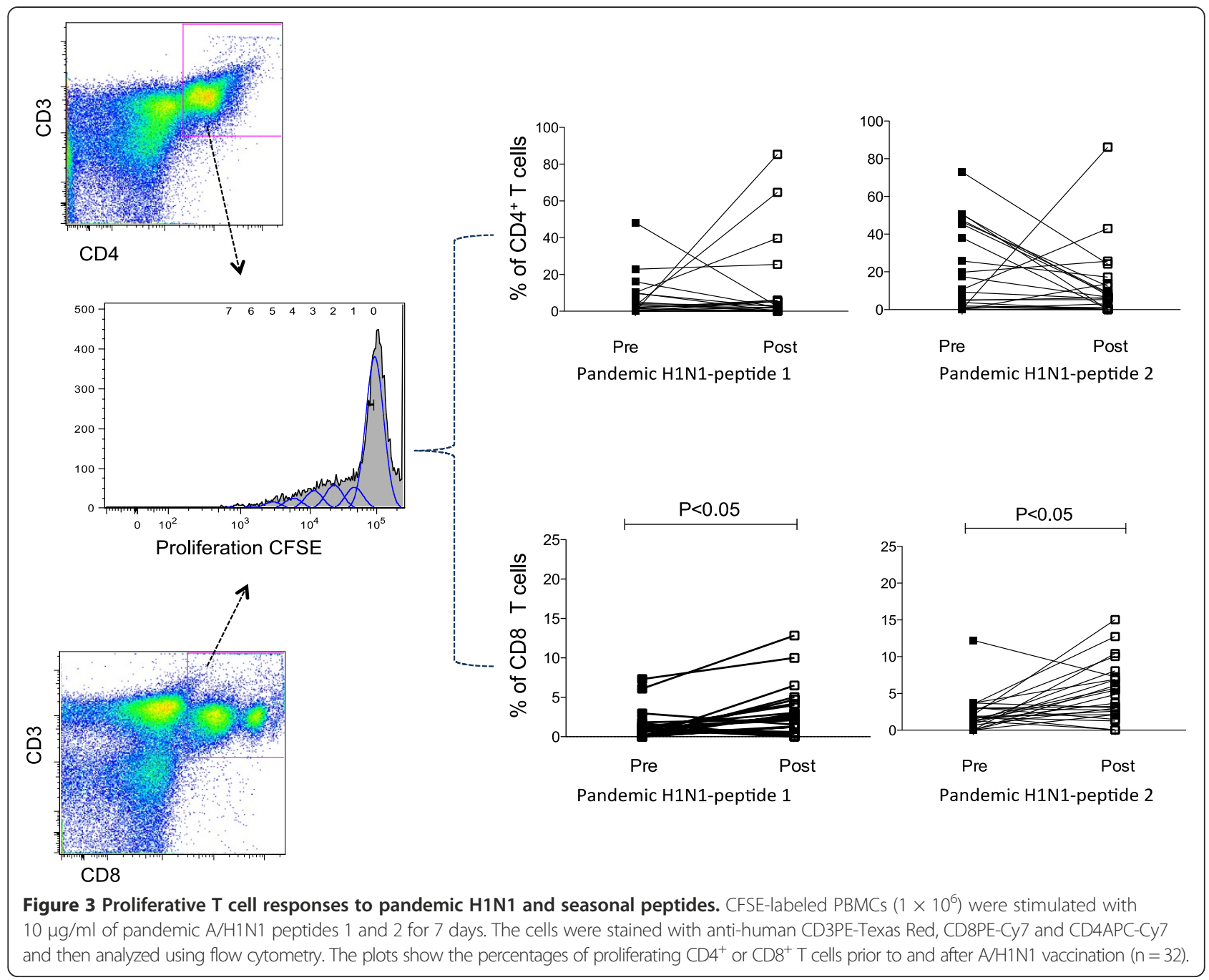

We do not believe that the lack of $\mathrm{CD}^{+}{ }^{+} \mathrm{T}$ cell proliferation was associated with limited class II peptide recognition by these cells because the selected A/H1N1 peptides ( 1 and 2 ) are predicted to have a high affinity for class I and class II recognition in the Mexican population (Additional file 1: Table S1). In the case of proliferative responses to $\mathrm{H} 1 \mathrm{~N} 1$ peptide 2, a decreasing trend was observed in $\mathrm{CD} 4^{+} \mathrm{T}$ cell proliferation, although this was not significant $(\mathrm{p}=0.45)$ (Figure 3 ).

It is possible that the lack of a significant increase in $\mathrm{CD}^{+}{ }^{+} \mathrm{T}$ cell proliferation after $\mathrm{H} 1 \mathrm{~N} 1$ vaccination may be due to a higher frequency of $\mathrm{CD} 4^{+} \mathrm{T}$ cells compared with $\mathrm{CD} 8^{+} \mathrm{T}$ cells prior to vaccination, which in turn could be induced by seasonal vaccination and/or natural exposure to the influenza virus. It is also possible that the absence of an adjuvant in the vaccine affected the proliferation of $\mathrm{CD}^{+} \mathrm{T}$ cells. Similar to our results, a previous report demonstrated that a non-adjuvanted H5N1 vaccine did not induce a robust expansion of $\mathrm{CD}_{4}^{+} \mathrm{T}$ cells and failed to increase specific antibody titers [33].
Therefore, our results indicate that either the $\mathrm{A} / \mathrm{H} 1 \mathrm{~N} 1$ vaccine had low $\mathrm{CD} 4^{+} \mathrm{T}$ cell immunogenicity or that the $\mathrm{A} / \mathrm{H} 1 \mathrm{~N} 1$ vaccine did not induce $\mathrm{CD} 4^{+} \mathrm{T}$ cell proliferation in individuals who had previously received the seasonal vaccine. In contrast to the $\mathrm{CD} 4^{+} \mathrm{T}$ cell responses, our results indicated that the $\mathrm{A} / \mathrm{H} 1 \mathrm{~N} 1$ vaccine induced significant $\mathrm{CD}^{+} \mathrm{T}$ cell proliferation in individuals who had previously received the seasonal vaccine. Additionally, we did not find a correlation between $\mathrm{CD} 4^{+}$or $\mathrm{CD} 8^{+} \mathrm{T}$ cell proliferation and the antibody production induced by vaccination.

In summary, our results indicate that pandemic vaccination induces $\mathrm{CD}^{+} \mathrm{T}$ cell clonal expansion, as demonstrated by the increase in the proliferative response to $\mathrm{A} / \mathrm{H} 1 \mathrm{~N} 1$ peptides. This result is consistent with previous reports demonstrating that $\mathrm{CD} 8^{+} \mathrm{T}$ cells proliferate after influenza vaccination $[28,31]$. We hypothesize that the extent of $\mathrm{CD}^{+} \mathrm{T}$ cell clonal expansion that we observed following $\mathrm{H} 1 \mathrm{~N} 1$ pandemic vaccination may be linked to the cytolytic effector functions of cells rather than the 
generation of antigen-specific long-lived plasma cells and the direct effector functions mediated by IFN- $\gamma$ [34].

Furthermore, to analyze the cross-reactivity of seasonal serotypes, we evaluated the percentages of $\mathrm{CD}^{+} \mathrm{T}$ cells proliferating in response to specific peptides corresponding to seasonal $\mathrm{H} 1 \mathrm{~N} 1$ and $\mathrm{H} 3 \mathrm{~N} 2$ serotypes. We found that approximately $5 \%$ of the $\mathrm{CD} 8^{+} \mathrm{T}$ cells proliferated in response to pandemic and seasonal peptides prior to vaccination (Figure 4a). This finding may be associated with previous seasonal vaccination because most of the individuals had received a seasonal vaccination approximately 2 months prior to the pandemic vaccination. However, this finding could also be associated with the presence of cross-reactive virus-specific $\mathrm{CD} 8^{+}$memory $\mathrm{T}$ cells, as reported by others [35]. Our results also showed a significant increase in $\mathrm{CD}^{+} \mathrm{T}$ cell proliferation in response to pandemic and seasonal influenza-specific peptides after pandemic $\mathrm{A} / \mathrm{H} 1 \mathrm{~N} 1$ vaccination $(\mathrm{p}<0.05)$ (Figures 3 and $4 \mathrm{a})$. No significant differences were detected in the percentage of proliferating $\mathrm{CD}^{+} \mathrm{T}$ cells between the pandemic and seasonal type A viruses. Among individuals with positive proliferative responses, $29 \%, 13 \%$ and $37 \%$ had pre-existing $\mathrm{CD}^{+} \mathrm{T}$ cells specific to the pandemic $\mathrm{A} / \mathrm{H} 1 \mathrm{~N} 1$, seasonal H1N1 and seasonal H3N2 peptides, respectively. One month after pandemic vaccination, the percentage of positive subjects increased to $70.8 \%(\mathrm{p}<0.05)$ for the pandemic A/H1N1 serotype and to $43 \%(\mathrm{p}<0.05)$ and $47 \%$ ( $>0.05$ ) for the seasonal H1N1 and H3N2 serotypes, respectively (Figure $4 \mathrm{~b}$ ). These data indicate that after pandemic $\mathrm{A} / \mathrm{H} 1 \mathrm{~N} 1$ vaccination, the number of individuals with antigen-specific proliferating $\mathrm{CD}^{+} \mathrm{T}$ cells increased; this assessment may serve as a complementary parameter for evaluating the immunological success of influenza vaccines.

\section{Conclusions}

Our results showed that cellular immune responses that are cross-reactive to pandemic influenza antigens may
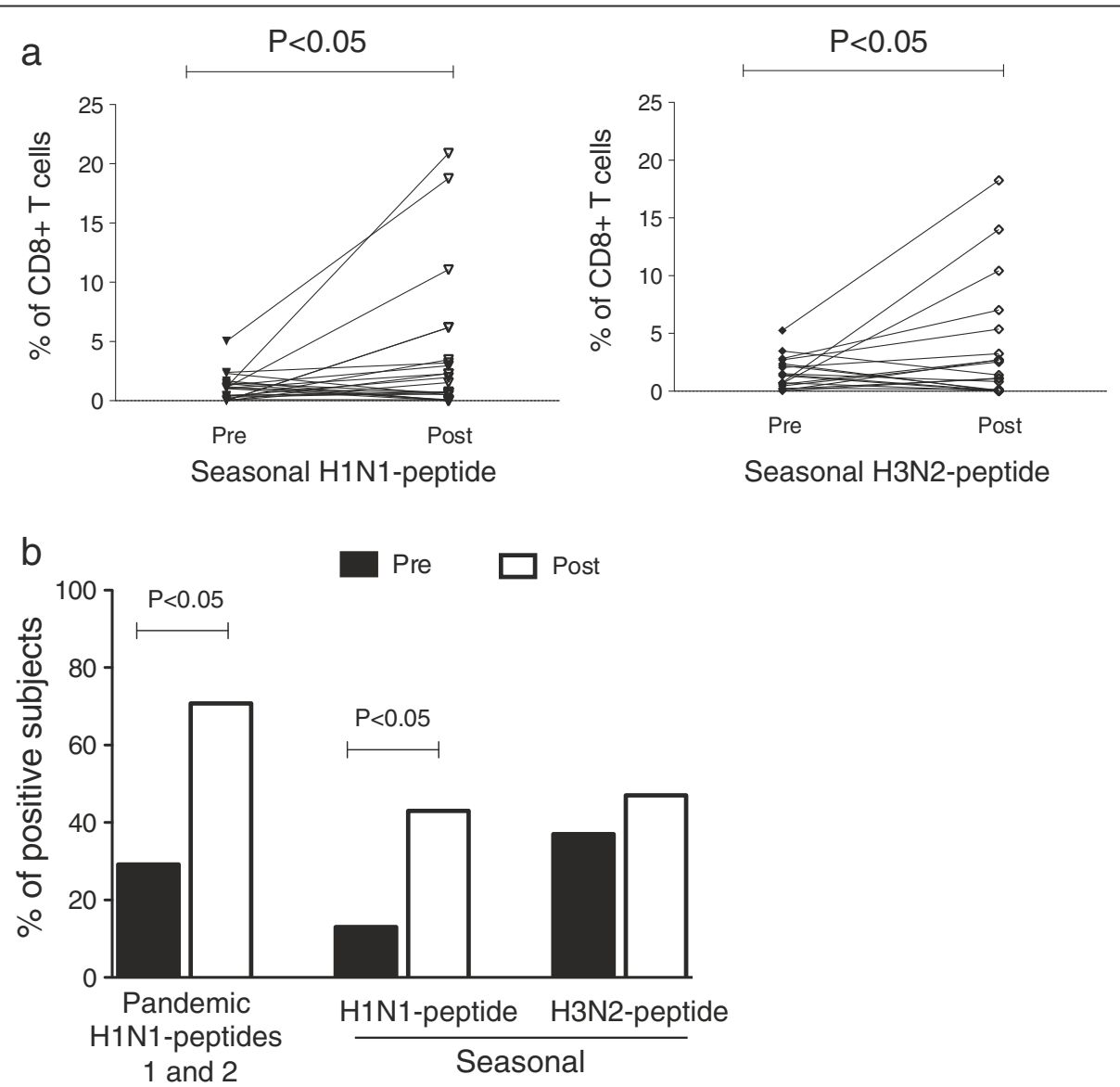

Figure 4 Pandemic H1N1 vaccination induced CD8 ${ }^{+}$T cell proliferation to pandemic H1N1, seasonal H1N1 and H3N2 peptides. CFSE-labeled PBMCs $\left(1 \times 10^{6}\right)$ were stimulated with $10 \mu \mathrm{g} / \mathrm{ml}$ of the pandemic $\mathrm{H} 1 \mathrm{~N} 1$ and seasonal $\mathrm{H} 1 \mathrm{~N} 1$ and H3N2 peptides for 7 days. The cells were harvested and stained with anti-human CD3PE-Texas Red and CD8PE-Cy7 and analyzed using flow cytometry. (a) Percentages of the CD8 ${ }^{+} \mathrm{T}$ cell proliferation pre-vaccination and post-vaccination in response to seasonal H1N1 and H3N2 peptides. The means and standard errors are shown, with $p \leq 0.05$ pre-vaccination vs. post-vaccination, according to the Wilcoxon matched-pairs signed rank test. (b) Percentages of positive subjects responding to the pandemic H1N1 peptides 1 and $2(p<0.05)$ and the seasonal influenza A H1N1 $(p<0.05)$ and H3N2 serotypes post-vaccination $(p>0.05)$. 
be present in populations exposed to the circulating seasonal influenza virus prior to pandemic or seasonal vaccination. The pandemic vaccine induced a significant increase in $\mathrm{CD}^{+} \mathrm{T}$ cell proliferation.

\section{Additional file}

Additional file 1: Table S1. Peptide sequences and predicted

recognition by class I and class II HLA alleles frequently found in Mexicans.

\begin{abstract}
Abbreviations
HA: Hemagglutinin; PBMCs: Peripheral blood mononuclear cells; ELISPOT: Enzyme-linked-Immuno-Spot; SFC: Spot-forming cell.
\end{abstract}

\section{Competing interests}

The authors declare that they have no competing interests.

\section{Authors' contributions}

MTH, FHS and CC performed the experiments, data analysis and results interpretation. MEM and CS performed the data analysis. SGB designed the peptide sequences. MMT performed the clinical analysis. EJ and YG made valuable contributions to the study's design, analysis and interpretation of the data and the written manuscript. ES and LGG participated in the study design and interpretation of the data. MT participated in the study design and wrote the manuscript. All authors reviewed and approved the final manuscript.

\section{Authors' information}

Eduardo Sada and Martha Torres, are authors share senior authorship.

\section{Acknowledgements}

We thank Dr. Irma López and Rodrigo Aparicio from the Diagnostics and Epidemiology Reference Institute (INDRE) for their assistance with the antibody measurements. This work was supported by the National Council of Science and Technology (CONACYT) grants 140942 and 126693.

\section{Role of the funding source}

The study sponsor did not participate in the study design, the collection, analysis and interpretation of the data, the writing of the report or the decision to submit the paper for publication.

\section{Author details}

${ }^{1}$ Department of Microbiology, Instituto Nacional de Enfermedades Respiratorias Ismael Cosío Villegas, Tlalpan 4502, Tlalpan, Mexico City 14080, Mexico. ${ }^{2}$ Department of Virology, Instituto Nacional de Enfermedades Respiratorias Ismael Cosío Villegas, Tlalpan 4502, Tlalpan, Mexico City 14080, Mexico. ${ }^{3}$ Centro de Investigacion sobre Enfermedades Infecciosas, Instituto Nacional de Salud Publica, Cuernavaca, Mexico.

Received: 18 June 2013 Accepted: 4 November 2013 Published: 15 November 2013

\section{References}

1. Chowell G, Bertozzi SM, Colchero MA, Lopez-Gatell H, Alpuche-Aranda C, Hernandez M, Miller MA: Severe respiratory disease concurrent with the circulation of H1N1 influenza. N Engl J Med 2009, 361(7):674-679.

2. Greenberg ME, Lai MH, Hartel GF, Wichems CH, Gittleson C, Bennet J, Dawson G, Hu W, Leggio C, Washington D, et al: Response to a monovalent 2009 influenza A (H1N1) vaccine. N Engl J Med 2009, 361(25):2405-2413.

3. Nolan T, McVernon J, Skeljo M, Richmond P, Wadia U, Lambert S, Nissen M, Marshall H, Booy R, Heron L, et al: Immunogenicity of a monovalent 2009 influenza $A(\mathrm{H} 1 \mathrm{~N} 1)$ vaccine in infants and children: a randomized trial. JAMA 2010, 303(1):37-46.

4. Wu J, Li W, Wang HQ, Chen JT, Lv M, Zhou JC, Liang XF, Fang HH, Liu Y, Liu LY, et al: A rapid immune response to 2009 influenza $A(H 1 N 1)$ vaccines in adults: a randomized, double-blind, controlled trial. $J$ Infect Dis 2010, 202(5):675-680.
5. Virus strains recommended by the World Health Organization for the development of the influenza A (H1N1) vaccines. http://www.who.int/csr/ resources/publications/swineflu/2009_05_27_X179Aa.pdf.

6. Zhou Y, Ng DM, Seto WH, Ip DK, Kwok HK, Ma ES, Ng S, Lau LL, Peiris JS, Cowling BJ: Seroprevalence of Pandemic H1N1 Antibody among Health Care Workers in Hong Kong Following Receipt of Monovalent 2009 H1N1 Influenza Vaccine. PloS One 2011, 6(11):e27169.

7. Phongsamart W, Sirisanthana V, Wittawatmongkol O, Maleesatharn A, Sudjaritruk T, Chearskul P, Aurpibul L, Sirisanthana T, Chokephaibulkit K: Immunogenicity and safety of monovalent influenza A (H1N1) 2009 in HIV-infected Thai children. Vaccine 2011, 29(47):8705-8711.

8. Van der Vliet D, Pepin S, Lambert M, Fauchoux N, Donazzolo Y, Dupuy M, Dakowski C, Denis M: Similar immunogenicity of the A/H1N1 2009 pandemic influenza strain when used as a monovalent or a trivalent vaccine. Hum Vaccin 2010, 6(10):823-828.

9. Plennevaux E, Blatter M, Cornish MJ, Go K, Kirby D, Wali M, Reeves-Hoche MK, Denis M: Influenza A (H1N1) 2009 two-dose immunization of US children: an observer-blinded, randomized, placebo-controlled trial. Vaccine 2011, 29(8):1569-1575.

10. Thomas PG, Keating R, Hulse-Post DJ, Doherty PC: Cell-mediated protection in influenza infection. Emerg Infect Dis 2006, 12(1):48-54.

11. Brown LE, Kelso A: Prospects for an influenza vaccine that induces crossprotective cytotoxic T lymphocytes. Immunol Cell Biol 2009, 87(4):300-308.

12. Schanen BC, De Groot AS, Moise L, Ardito M, McClaine E, Martin W, Wittman V, Warren WL, Drake DR 3rd: Coupling sensitive in vitro and in silico techniques to assess cross-reactive CD4(+) T cells against the swine-origin H1N1 influenza virus. Vaccine 2011, 29(17):3299-3309.

13. Ge X, Tan V, Bollyky PL, Standifer NE, James EA, Kwok WW: Assessment of seasonal influenza A virus-specific CD4 T-cell responses to 2009 pandemic H1N1 swine-origin influenza A virus. J Virol 2010, 84(7):3312-3319.

14. Tu W, Mao H, Zheng J, Liu Y, Chiu SS, Qin G, Chan PL, Lam KT, Guan J, Zhang L, et al: Cytotoxic T lymphocytes established by seasonal human influenza cross-react against 2009 pandemic H1N1 influenza virus. J Virol 2010, 84(13):6527-6535.

15. NCBI FASTA. http://www.ncbi.nlm.nih.gov/genomes/FLU/Database/nphselect.cgi?go=alignment.

16. Falfan-Valencia R, Camarena A, Juarez A, Becerril C, Montano M, Cisneros J, Mendoza F, Granados J, Pardo A, Selman M: Major histocompatibility complex and alveolar epithelial apoptosis in idiopathic pulmonary fibrosis. Hum Genet 2005, 118(2):235-244.

17. Singh H, Raghava GP: ProPred: prediction of HLA-DR binding sites. Bioinformatics 2001, 17(12):1236-1237.

18. WHO: Manual for the laboratory diagnosis and virological surveillance of influenza. Geneva, Switzerland: WHO Press; 2002:153.

19. Guideline on influenza vaccines prepared from viruses with the potential to cause a pandemic and intended for use outside of the core dossier context. In Committee for Human Medicinal Products, Doc Ref. EMEAVCHMPMWP/263499/ 2006. London, United Kingdon: European Medicines Agency; 2007

20. Schwander SK, Torres M, Sada E, Carranza C, Ramos E, Tary-Lehmann M, Wallis RS, Sierra J, Rich EA: Enhanced responses to Mycobacterium tuberculosis antigens by human alveolar lymphocytes during active pulmonary tuberculosis. J Infect Dis 1998, 178(5):1434-1445.

21. Duvvuri VR, Duvvuri B, Jamnik V, Gubbay JB, Wu J, Wu GE: T cell memory to evolutionarily conserved and shared hemagglutinin epitopes of $\mathrm{H} 1 \mathrm{~N} 1$ viruses: a pilot scale study. BMC Infect Dis 2013, 13:204.

22. Randles RH: WD: Introduction to the Theory of Nonparametric Statistics. New York: John Wiley \& Sons; 1979.

23. Wagar LE, Rosella L, Crowcroft N, Lowcock B, Drohomyrecky PC, Foisy J, Gubbay J, Rebbapragada A, Winter AL, Achonu C, et al: Humoral and cell-mediated immunity to pandemic H1N1 influenza in a Canadian cohort one year post-pandemic: implications for vaccination. PloS one 2011, 6(11):e28063.

24. Lagler H, Grabmeier-Pfistershammer K, Touzeau-Romer V, Tobudic S, Ramharter M, Wenisch J, Gualdoni GA, Redlberger-Fritz M, Popow-Kraupp T, Rieger A, et al: Immunogenicity and Tolerability after Two Doses of Non-Adjuvanted, Whole-Virion Pandemic Influenza A (H1N1) Vaccine in HIV-Infected Individuals. PloS one 2012, 7(5):e36773.

25. Li GM, Chiu C, Wrammert J, McCausland M, Andrews SF, Zheng NY, Lee JH, Huang M, Qu X, Edupuganti S, et al: Pandemic H1N1 influenza vaccine induces a recall response in humans that favors broadly cross-reactive memory B cells. Proc Natl Acad Sci U S A 2012, 109(23):9047-9052. 
26. Choi YS, Baek YH, Kang W, Nam SJ, Lee J, You S, Chang DY, Youn JC, Choi YK, Shin EC: Reduced antibody responses to the pandemic (H1N1) 2009 vaccine after recent seasonal influenza vaccination. Clin Vaccine Immunol 2011, 18(9):1519-1523.

27. Air GM, Feng J, Chen T, Joachims ML, James JA, Thompson LF: Individual antibody and $T$ cell responses to vaccination and infection with the 2009 pandemic swine-origin H1N1 influenza virus. J Clin Immunol 2011, 31(5):900-912.

28. Iorio AM, Bistoni O, Galdiero M, Lepri E, Camilloni B, Russano AM, Neri M, Basileo M, Spinozzi F: Influenza viruses and cross-reactivity in healthy adults: humoral and cellular immunity induced by seasonal 2007/2008 influenza vaccination against vaccine antigens and $2009 \mathrm{~A}(\mathrm{H} 1 \mathrm{~N} 1)$ pandemic influenza virus. Vaccine 2012, 30(9):1617-1623.

29. Greenbaum JA, Kotturi MF, Kim Y, Oseroff C, Vaughan K, Salimi N, Vita R, Ponomarenko J, Scheuermann RH, Sette A, et al: Pre-existing immunity against swine-origin $\mathrm{H} 1 \mathrm{~N} 1$ influenza viruses in the general human population. Proc Natl Acad Sci U S A 2009, 106(48):20365-20370.

30. Mahnke YD, Saqr A, Hazenfeld S, Brady RC, Roederer M, Subbramanian RA: Age-related changes in durability and function of vaccine-elicited influenza-specific CD4(+) T-cell responses. Vaccine 2011, 29(47):8606-8614.

31. Scheible K, Zhang G, Baer J, Azadniv M, Lambert K, Pryhuber G, Treanor JJ, Topham DJ: CD8+ T cell immunity to 2009 pandemic and seasonal H1N1 influenza viruses. Vaccine 2011, 29(11):2159-2168.

32. Roman F, Clement F, Dewe W, Walravens K, Maes C, Willekens J, De Boever F, Hanon E, Leroux-Roels G: Effect on cellular and humoral immune responses of the AS03 adjuvant system in an A/H1N1/2009 influenza virus vaccine administered to adults during two randomized controlled trials. Clin Vaccine Immunol 2011, 18(5):835-843.

33. Stephenson I, Hayden F, Osterhaus A, Howard W, Pervikov Y, Palkonyay L, Kieny MP: Report of the fourth meeting on 'Influenza vaccines that induce broad spectrum and long-lasting immune responses', World Health Organization and Wellcome Trust, London, United Kingdom, 9-10 November 2009. Vaccine 2010, 28(23):3875-3882.

34. Strutt TM, McKinstry KK, Dibble JP, Winchell C, Kuang Y, Curtis JD, Huston G, Dutton RW, Swain SL: Memory CD4+ T cells induce innate responses independently of pathogen. Nat Med 2010, 16(5):558-564. $551 \mathrm{p}$ following 564 .

35. Boon AC, de Mutsert G, van Baarle D, Smith DJ, Lapedes AS, Fouchier RA, Sintnicolaas K, Osterhaus AD, Rimmelzwaan GF: Recognition of homo- and heterosubtypic variants of influenza A viruses by human CD8+ T lymphocytes. J Immunol 2004, 172(4):2453-2460.

doi:10.1186/1471-2334-13-544

Cite this article as: Herrera et al: Humoral and cellular responses to a non-adjuvanted monovalent $\mathrm{H} 1 \mathrm{~N} 1$ pandemic influenza vaccine in hospital employees. BMC Infectious Diseases 2013 13:544.

\section{Submit your next manuscript to BioMed Central and take full advantage of:}

- Convenient online submission

- Thorough peer review

- No space constraints or color figure charges

- Immediate publication on acceptance

- Inclusion in PubMed, CAS, Scopus and Google Scholar

- Research which is freely available for redistribution

Submit your manuscript at www.biomedcentral.com/submit
C BioMed Central 